\title{
The Poetics of Space in Nâzım Hikmet's Poem, Straw-Blond ${ }^{\mathrm{i}}$
}

\author{
Efe Duyan
}

Department of Architecture, Mimar Sinan Fine Arts University, Turkey

Received August 27, 2019; Revised November 25, 2019; Accepted December 4, 2019

Copyright $\odot 2020$ by authors, all rights reserved. Authors agree that this article remains permanently open access under the terms of the Creative Commons Attribution License 4.0 International License

\begin{abstract}
This study investigates the understanding of space in Nâzım Hikmet's poem Straw-Blond and the central role it plays in the composition of the text. Straw-Blond represents a diversion in the oeuvre of Hikmet, a politically controversial and arguably still the most beloved poet in Turkey, who is well-known for his realistic approach and linear narration. A train journey in the background, the text includes descriptions of several cities and places while dealing with the idea of loss in shapes of separation, exile, and aging. The unique way of how space is conceived can be summed up by the sudden and ceaseless jumps from one location to another, either to a geographically different place or to a moment in the past. This surreal network of spaces composed of places in different locations and times leads to a non-linear narration of a fast tempo that refers to the inevitability of the passing of time and it creates an extremely vague and uncanny atmosphere, which, in return, feeds the central theme of the fear of the loss. All the locations from different cities and times are interlinked in a way that the spatial composition of spaces takes center stage as an instrument of narration. Thus, the flow of spaces creates a unique architecture of narration.
\end{abstract}

Keywords Space in the Narrative, Narrative Space, the Theory of Architecture, Nâzım Hikmet, Modern Literature, Poetry

\section{Introduction}

This paper will analyze the use of spaces and places in Nâzım Hikmet's poem Straw-Blond and their effect in the text. First of all, the key concepts to define the space in narration will be outlined. The main element of the analysis is the spatial frame, which is a space created by textual means. How the spaces relate to each other in terms of composition is another critical issue. The thematization of the space will also be mentioned, as the spaces and places are not merely containers of the storyline but also act as the means of representation.

Secondly, a framework of Hikmet's poetry will be provided to denote the key features of his poem Staw-Blond. On the one hand, as an avant-garde artist from 1920s on, Hikmet's attitude to reinvent himself is to be noted as it is this reflex that paved the way to a poem as distinctive as Straw-blond. His poetry, in general, is easy to grasp and realistic on the other hand, except the formative years and late poems (the Straw-Blond in particular).

Hikmet's use of space in his poems will follow, in parts separated as realistic descriptions of individual locations and abstract images of space. His realistic point of view laid the ground for the frequent inclusion of accurate descriptions of places. There are other examples, though, where he used the space as an abstract image and in a representative way to signify an emotion or an idea.

After that, an analysis of Straw-blond will be undertaken based on Hikmet's use of spaces. It will show how he tries to make an emotional impact using the transitions between the spatial frames. His use of space in Straw-blond will be associated with the general composition of the poem to exhibit how he uses the space as the critical element of his narrative and to point out the unique spatial understanding of the text, which can be claimed to have a backbone of the spatial composition.

\section{A Conceptual Framework for a Spatial Analysis of Narration}

Straw-blond presents numerous individual locations, in which narratively significant events take place or which are directly associated with the main themes. The individual locations will be considered as the main element of the spatial analysis. The immediate surroundings of actual events, a specific moment in time and a specific three-dimensional space is defined as a spatial frame 
(RYAN). Space-referential means can be used, such as toponyms, proper names, generic terms, deictic terms, and concrete nouns. Space can be narrated in various ways as "it can be mentioned by the narrator (...), anthropomorphized, allegorized, perceived or described or it can be the setting or the object of reflections" (DENNERLEIN, 8). While the space as the object of description usually gives a detailed architectural account, space as presented during narration, the natural and imperative surrounding of the body and perception, will also be considered of equal significance. A narrative universe, on the other hand, is "the world presented as actual by the text, plus all the counterfactual worlds constructed by characters as beliefs, wishes, fears, speculations, hypothetical thinking, dreams and fantasies" (RYAN), and the universe created in the poem will be dwelt upon to frame the general atmosphere of the text.

How the spatial information is conveyed raises the issue of narrativization of space, which is the dynamic representation of the spatial information throughout the text that develops in time. It is a type of narrative organization by networks of semantic, phonetic or more broadly thematic relations between textual units. It is a formal pattern, a network of analogical relations -a composition of the text with all types of interrelated elements and links visualized (DENNERLEIN, 12).

How the parts of the text depicting a space are linked to each other is playing a crucial role in the composition of the Straw-blond. The extreme geographical gaps between each adjacent spatial frame will be examined, as well as the time differences between each scene.

A third concept is the thematization of space, which the attribution of symbolic meaning to the various regions and landmarks of the narrative world (RYAN). Space is not only a container surrounding the characters, but it can also be deliberately associated with certain emotions to act as a metaphor (PARKER, 10). In Straw-blond most of the spatial frames (even real places or cities) directly refer to several themes as metaphors. They may be described in detail, or they may well be only ambiguous surroundings, in either case, they have a function of a metaphor, a function that goes beyond serving as a container to the plot. The use of spaces in Straw-Blond acts as the "objective correlative," which T. S Elliot describes "a set of objects, a situation, a chain of events which shall be the formula of that particular emotion." (ELIOT, (1921) According to him, there must be a connection between the emotion the poet is trying to express and the object, image, or situation in the poem that helps to convey that emotion to the reader "such that when the external facts, which must terminate in sensory experience, are given, the emotion is immediately evoked" (ELIOT, 1921). Eliot analyzed Shakespeare's Hamlet and determined 'that it was an "artistic failure" because Hamlet's intense emotions overwhelmed the author's attempts to express them through an objective correlative. In other words, Eliot felt that Shakespeare was unable to provoke the audience to feel as Prince Hamlet did through images, actions, and characters, and instead only inadequately described his emotional state through the play's dialogue."(OBJECTIVE CORRELATIVE, 2019) Hikmet's method, on the other hand, aims at conveying the main complicated and mixed feeling of the poem through the spaces, thus making his frames to work as objective correlatives.

To sum up, the main method of analysis of the text is to figure out how the single spatial frames are linked to each other in terms of the composition of the text. The key to the whole poem is to exhibit the way spatial frames are brought together, which are constantly changed in a flash in a cinematographic fashion with direct-cuts. Moreover, the general metaphor of the whole text is generated by converting the individual places visited during a journey into elements of a metaphor. Jumping from frame to frame with direct-cuts renders them uncanny and surreal and, thus, metaphorically connects the journey itself to the various themes of the poem.

\section{Hikmet's Poetry and His Use of Space}

The life of a well-educated and patriotic young poet from the Ottoman capital of Istanbul, Nâzım Hikmet, took a serious turn when he decided to travel to Anatolia to take part in the war of independence as his interest to Soviet revolution was going to lead him to Russia soon afterward. He was thoroughly fascinated by the upheaval of society and decided to stay in Moscow to continue his education, where he has stayed until the end of the decade. Influenced by the Futurist-Constructivist art scene, he grew into a notable member of it. The years in the Soviet Union shaped Hikmet's understanding of the world as a political activist and also brought out of him a futurist poet utterly convinced of the functional role of art as a means of social engineering and of the necessity to cut the ties with the tradition.

On his return to Turkey in 1929, he shocked the intellectual community not only with his experimental poetry but also with his self-confident and antagonistic attitude towards the modestly modernized literature scene. (FUAT) However, when the global political waves of nationalism hit Turkey in the 1930 s, the country started to renounce its process of rapid modernization, so did Hikmet his meteoric futurism. His language softened and became more communicative. The way he treats political propaganda in terms of very personal and concrete emotions paved the way of his fame, but a figure of Hikmet's popularity with a left-wing political agenda in times of nationalism was always going to be suppressed. Fake trials condemned him to prison, and he was released after 13 years thanks to an international campaign to free him. Followed by the police and worried about the death 
threats, he was forced to leave Turkey for good. (KARACA, 2011)

After an adventurous escape via the Black Sea, he lived in Moscow for the rest of his life as an exile and a cultural attaché. Whereas his productive late years includes various forms, varying from anthem-like propaganda poems to experimental prose poems, his poetry has always been extremely communicative and realistic with a lyrical tone so that his narrative attitude opened up countless descriptions of spaces and places. As an avant-garde artist, tough, he tried to reinvent himself many times, which also gave way, above all, the sui generis Straw-Blond itself, one of his late travel poems.

His life as a cultural attaché included various trips to several countries except for Turkey itself. It was like an everlasting condition of being on the road yet never reaching its ultimate goal, which is returning to his hometown, Istanbul. This dilemma may have inspired Straw-blond, an experimental journey poem to host a different kind of anxious and complicated set of emotions as well as an extremely distinct style generated through a specific way of understanding space. Straw-Blond, a synthesis of his political stance and a surrealist experiment. The central theme of the poem, a long journey through different cities and times, also acts as a symbol reasoning of decisions and life. The spaces and places, thus, are functioning on two different layers, the realistic and the symbolic one. The flow of spaces holds the worlds together, a real journey and life as a journey. On that basis, the journey as the main two-fold main instrument creates opportunities to bring up various topics. Staw-blond's spaces of journey create the primary poetic methodology for a one-time experiment in bringing realist narration and avant-garde surrealism together.

Straw-blond can be considered as a climax of long career and also a example of much changed attitude throughout the years. His early poems rarely include real spaces, and those were linked to a romanticized view of Anatolia while he was still living in an Istanbul under siege as a young patriotic teenager. His futuristic poetry after the encounter with Constructivism was based on describing movement by sounds and scenes. The Weeping Willow, a requiem, is full of alliterations and experiments to support the meaning through the sound of the letters: "Sudden / -ly like a bird / shot / in the wing / a wounded horseman tumbled from his horse"(trans. by Ruth Christie) (1). Those lines aim to recreate the sound and movement of the fall of a Red Army soldier during a Soviet Civil War battle. "Horsemen, horsemen, red riders, / horses wind winged / horses wind wing / horses wind / horses / horse." (trans. by R. Christie) The dying moment of the soldier watching the rest of the riders became distant and thus, smaller.

This cubo-futuristic attitude to use the medium itself, the two-dimensional white page as the spatial extension of the text, was much common than the spatial depictions themselves. Space itself was either an extension of the text in a Mayakovskian way or a utopic surrounding for his propaganda poems. Still, he was dealing with the physical environment.

Nâzım Hikmet's poetry since the mid-1930s is a combination of the lyrical expression of the self and political functionalism. Both inclinations paved the way for extensive narration so that an interest to include places set off. His fantasy-crime romance Giaconda and $S \dot{I}-Y A-U$ and the fictional alternative history Why did Benerci Kill Himself? It can be considered a period of transition towards epic poems with a dramatic structure and characters (DUYAN). At the same time, in the 1930s, he has started to use a simpler language in line with the cultural inclination of the era of national regionalism. The anti-fascist resistance story of Letters to Taranta-Babu and the historical poem of The Epic of Shaykh Bedreddin can be considered steps towards his epic masterwork of Human Landscapes from my Country, a kind of poetry-novel with a cinematographic flux, which was going to be written in the 1940s in prison (ÖZER).

Human Landscapes from My Country, his poetic novel written in the 1940s in prison, demonstrates that he mastered the poetic narration and cinematographic techniques. Spaces are described in detail as part of the narration to support the narrative act. His way of thematization can also be observed from the well-known opening scene on, including dozens of characters climbing up or down the monumental stairs of Istanbul's main train station. "Sun, exhaustion, and rush lay on" the stairs of the Haydarpaşa Station, a point of numerous encounters and a hectic rush, while, in contrast, the waiting lounge evokes a state stasis and a moment of contemplation. The epic poem of nearly twenty thousand lines contains various spatial frames to demonstrate the poverty and injustice in the society in parallel to the realistic story arcs. The visual character of the prose-poem is strong as he is using the visual techniques of modern theatre and cinema. (ÖZER)

After long imprisonment for his political activities, Hikmet ultimately left Turkey in 1951 to spend the rest of his life in the Soviet Union, where he was welcomed as a cultural attaché. The life as an exile was full of traveling and longing to his hometown, which he was not allowed to return by any means. It is no surprise that his poetry of this period from 1951 to 1963 obtained a special agenda related to places, cities, and geography. A strong emphasis on spatial narration can be noticed, although his poems, do obviously not contain as many detailed descriptions as one would expect in a novel. Still, the emphasis on spatial images and real places around the idea of homesickness opened up various strategies, and the poems of referencing and depicting real places are to be written more often than not. For example, the Hotel Bor in Bulgaria, the other side of the Black sea, where talks about not being able to sleep as memories arouse because of details evoking Turkey. Slavia Restaurant in Prague, where he dramatizes the toughness of life as an author and the beauty of Prague in 
spring. Looking at the towns and places, one comes across a variety of them from Havana Libere Hotel to Uzbeki Gardens in Cairo. All those places and cities act as the setting of his complicated situation or acting as landmarks in the text to evoke complex emotions.

Hikmet's limited but explicit spatial descriptions never ceased to exist, nor his ability to attach spaces to certain conditions to thematize them, such as longing, unfairness, political anger, or passion, which means that there are also some other passages from his period of exile containing spatial frames in an abstract way. On separate occasions, we can observe the opposite of concrete fictional space, the space as an abstract and intangible entity as a part of a philosophical argument, echoing his early futuristic times. Those poems, with more symbolically thematized spaces, are eye-catching but rare, as Hikmet was never intended to sail away far from his realist realm. In Snowy Beech Forest, a rhyming poem, Hikmet contemplating about himself ("Is my country the farthest / away, or my youth or the stars / a window in the beech forest / glows yellow-warm"), where the Beech forest is an obvious symbol for the lifetime. Times in Prague ("in Prague, the baroque slowly lights up / uneasy, distant / its gilt grief-blackened/the statues on Charles Bridge / look like birds descended from a dead star"), is one of the poems, where cities are conceived as an obscure and symbolic urban environment. Whereas there are also a few poems connecting architecture to certain ideas, such as Windows, where he personifies the windows, or Houses, where he briefly mentions the democratic aspects of architecture, it is his poem Building and Builders, where space itself is an element on the forefront. The text is a straightforward allegorical parable of Soviet socialism, which he was not going to refrain from criticizing later on: "A building cannot be constructed like singing a song. (...) There is heartbeat / In each beam, each brick, each cement. / The building rises / and rises / and rises in blood and sweat." (trans. by the author)

\section{Straw-Blond: An Analysis of the Relations of Spaces}

Straw-Blond, the late masterpiece of Nâzım Hikmet, offers a synthesis of space as a symbol and a real place. A new instrument of the poetic composition emerges to forge this synthesis, namely the flow of spaces as an element of rhythm. The poem is a long text dealing with several themes, the passing of the time and the journey being the main double-central concepts to open up other topics. They create a teeter-totter, as either the time is passing or there is a change of location. This constant mode of motion is reflected in all other themes.

The first theme of the poem is the distance between the poet and the beloved, Vera Tulyakova, who obviously gives the poem its title. The distance mentioned in the text is open to interpretation as it can be the sign of a strained marriage as well as merely being physically separated due to the constant trips in an otherwise passionate relationship. The homesickness of the poet in exile is the second theme contrasting the joy of traveling as well- known and respected international poet. A third theme is the distance between the person who he was and who he is now; or, simply put, it is about getting old. The poet imagines meeting himself at 19 years old, where he settles the account with his ideological vision of the early 1920s, "when the poet and the Communist were one." (BLAZING) But the awareness of the widening gap is not only political; it is also related to the simple nostalgia of the good old times. There is one more dimension to the poem if not a theme, which is a historical narrative attached to the poem to offer Hikmet's political stance on certain historical moments such as Germany's invasion of Poland and the Cuban revolution.

Straw-Blond, tracing multiple journeys and dealing with the passing of time, offers a complex set of interrelated topics. All of those themes are interconnected through the double-concepts of time and space or elapse and movement.

The main double-concepts, the time and the journey, are embodied by means of the movement through spaces: a frenetic, alienating, and even surreal succession of spatial frames. The rapid transition from one spatial frame to another is the leitmotiv of the whole structure. The way, how the spatial frames are connected to each other, lays down the main style of the poem about the passing of time and travels evoking a complex set of emotions.

The first lines of the first part depict a scene at the Warsaw train station, "at dawn the express entered the station unannounced / it was covered with snow / I stood on the platform my coat collar raised," announcing the start of a journey in an ambiguous atmosphere. The image of a young woman sleeping in the lower berth of the carriage is followed by the line "I didn't see who was sleeping in the upper berth." At this very moment, the first jump of the poem occurs: "I watched it leave / I was sleeping in the upper berth / in the Bristol Hotel in Warsaw / I hadn't slept so soundly in years" Is he the one on the upper berth or is he the one watching the train leave? How did he go to the hotel? Is it the same woman who is sleeping beside him in "wooden and narrow bed" in the hotel? The only explanation would be that the station and carriage defining different times and the jump happens through a sharp direct-cut. Both locations, the hotel room, and the train's sleeper seem to be interchangeable, and all the other locations to follow are going to be interchangeable as well. The line "time sped on we were nearing midnight," is where the narrator gives a clue that the poem is about to play more and more with space and time. Just like the jump between the spatial frames, Hikmet jumps onto another theme, getting older: "inside mirrors I'm coming down the stairs / I could be twenty I could be a hundred." He starts to remember scenes from his earlier visits to the hotel. 
Unexpected aphorisms and metaphors in-between are added to the memories; like "drinking the loss of our cities drop by drop" or "the doorman saw me off his cloak sinking into the night" further visualizing the text.

In the second subpart, after remembering several moments in the hotel, the narrator leaves the hotel, and he goes further back in time to come across a squad of zombie Nazi soldiers with "animal fear" but "no heads" and shooting around nonstop without seeing anything (2). The line "time speeds on midnight approaches," seems to be acting as a break character signaling a change in topic. This historical moment, the fear and shock of the dead SS squad creates a contrasting moment of the revitalized and reconstructed Warsaw, "but there it was standing before them / like a hot loaf of bread in the icy night wind." It is a surreal vision referencing a historical moment as "the dead even an SS squad the dead can't kill / the dead kill by coming back as worms inside the apple." The narrator asks "wasn't [the city] killed before they were" to sum up the tragedies the city had to live through and adds break line "time sped on I was nearing midnight" to change the setting.

The third subpart begins as he suddenly jumps from the dreamy historical vision of the occupied Warsaw to a personal memory inside the Belvedere Palace in the same city, where Hikmet got "his first and maybe last medal." Receiving an award, Hikmet feels satisfied after all those years of suffering. It gives a vivid description of the palace, the Belvedere road, and the woman, whose "her hair straw-blond eyelashes blue." While he is entering the hall during the ceremony, he notices that "no one was there but us two / plus the aquarelles and delicate chairs and sofas like doll furniture / and you became / a blue-tinted pastel or a porcelain doll." After the ceremony, the poem changes city without warning, and the plot continues in the present time again.

The Caprice Bar in Krakow is the setting now, and the uneasy feeling of "separation" becomes the main theme in a blink. He feels anxious because of the distance to the Straw-Blond woman. Whether this "separation" is a physical distance, or the possible end of the relationship or implying a looming end of his life is not clear. In this passage, he talks about separation as if it is an object inside the space: "separation was on the table between the coffee cup and my glass / you put it there." After numerous metaphors, covered with a sense of hurry and fear of loss, he concludes that "separation was free of gravity weightless I can't say like a feather / even a feather weighs something separation was weightless / but it was there" It is a chain of sentences articulated to each other, breaking the simple language as a brief passage of stream of consciousness. Right afterward, a variation of the break line appears ("time speeds on midnight approaches us") and once again he suddenly jumps to his memories to enter to the next subpart.

The narrator gives a historical, an almost poesie-touristic account of Krakow. Hikmet mentions the "devil" roaming "Jagiellonian University / digging his nails into the stones" to imply the struggle against the religious conservatism in the middle ages. Loosely referencing the historical events, he mentions the salt mines and the workers there ("the red glow of Nowa Huta lights the clouds"). He also tells the mythical story of the trumpeter who has been killed while watching out for the enemy from the bell tower of the St. Mary's Church. This account of Krakow underlines the ephemeral impressions of the city from the previous subpart, and the evanescence of his feelings.

The real historical context of Warsaw and the poesie-touristic vision of Krakow is followed by Prague, another subpart stamped by the concept of emptiness. "Prague was all rain" reads its first line, and it continues as "an inlaid silver chest at the bottom of a lake / I opened it / inside a young woman slept among glass birds / her hair straw-blond eyelashes blue." The repetitive elements such as "her Hair straw-blond eyelashes blue" keep popping up to interrupt the flux and to bind the text to the earlier passages as an element of rhythm. Prague, defined through the absence of straw-blond woman, exaggerated as being completely empty. A complicated and grammatically decomposed passage reflects this emptiness by a moment of delirium full of yearning: "and in this loneliness enfolding the city like fog an old man try- / ing to shake off the sadness of age made ten times worse by / loneliness throws bread to the gulls from Legionnaires Bridge." After that passage on emptiness, which is actually another urban vision, Hikmet mixes the time and space by mentioning "I want to catch the times /the gold dust of their speed stays on my fingers."

One of the break-lines "a woman sleeps in the lower berth in the sleeper / she hasn't slept so soundly in years," appears to make the reader aware that another subpart is about to start by jumping to another city. This time, the setting is a carriage of the train bringing him back to Moscow, where he is welcomed by the straw-blond woman -only to make it clear that this brief moment of happiness belongs to a moment in the past, after which he actually "lost" her. This subpart, therefore, is about the search of the straw-blond woman. The emptiness of Prague is replaced by the rash of a hide-and-seek in the streets of Moscow and Istanbul: "Moscow was happy I was happy we were happy / suddenly I lost you in Mayakovsky Square I lost you suddenly no / not suddenly because I first lost the warmth of your hand in / mine then the soft weight of your hand in my palm and then / your hand". People and places like Strastnoi Monastery, Bolshoi Theatre, Red Square or restaurants in Istanbul are mentioned. The poet comes across some acquaintances and asks several people if they did see her or not. Several places from Moscow, Istanbul, or Prague appears just to disappear suddenly, and the language once again becomes decomposed and difficult to follow. This search through different times and cities connect different spaces as if they have a physical 
connection: "I asked the guards / didn't you see / (...) we didn't see / a tugboat breasts the current at Seraglio Point in Istanbul / behind it three barges/ awk awk the seagulls go awk awk /I called out to the barges from Red Square I didn't call to the / tugboat captain because he wouldn't have heard me over the / roar of his engine besides he was tired and his coat had no / buttons / I called out to the barges from Red Square / we didn't see". In the end, he comes across his own 19-year-old self when the world was "the taste of a green apple in his mouth," and as a conclusion, he accepts that "the minutes are ahead [of him] although he has "raced [them]"

The first main part includes many spaces from different cities and times, which, all together constitute a visual composition based articulation at a high tempo. The constant space and time jumps depict an allegorical and surreal journey, where the time itself is extremely relative. The absence of the beloved, hometown, and the youth are dealt with the constant change of spatial frames to create an unstable, volatile, and unreliable universe.

The second main part of the poem starts by mentioning different memories from Istanbul, Paris, Moscow, and Havana in the years 1921 or 1961 as if they all belong to one moment and a single city: "my nineteenth year crosses Beyazit Square comes out on Red Square / and goes down to Concorde I meet Abidin and we talk squares" The idea not only remains the same, but it becomes much stronger, as if all cities and all the places are adjacent to each other to compose a surreal mega-city of the parts from the places mentioned. The main difference is that the train journey is replaced with the river as the symbol of the movement. The poem talks about paintings with dynamic lines Gagarin's cycle around the world and Rumi's whirling to visualize the idea of motion. In one of the prose-poem style passages, Hikmet further comments on time and space in relation to painting: "the way I can see and catch fish in water that's how I see and / catch the bright moments flowing on Abidin's canvas" The motion itself, then, becomes the main theme instead of the previous themes, such as the distance beloved, homesickness, or aging. The main setting is the attic of the well-known Turkish painter Abidin Dino in Paris as the idea of motion is further underlined with images from the Seine river to recall the uneasiness of the passing of time: "how many more times will I lose her and find her / that's the way it is girl that's how it is I dropped part of my life / [...] the part of my life will flow with the Seine into the great cemetery of rivers". He concludes that the temporariness is something to be partly accepted, partly only observed and partly celebrated: "woke to the rustle of blood in my veins / my fingers weightless" On the other hand, arts may offer a cure, as he asks his painter friend Abidin in his famous line "can you paint the happiness Abidin?"

Hikmet, just like the previous depiction of Nazi occupation in Poland, starts to depict the Cuban revolution in detail as another historical attachment. After a long passage on how the revolution changed the life of the Cubans, he once again asks "can you paint freedom the kind without lies / night is falling in Paris", so that the final subpart opens up, where Hikmet mediates about "their craft", the artistic creation, and the role of the arts in history.

He concludes that it is only the river of art that starts from pre-historic times and that "all streams run into it with their new fish new water-grasses / new tastes and it alone flows endlessly and never dries up" Still, that the craft of the artist, which has always been in constant change, can be part of the change itself, which, historically, may also be the key to a utopic future. This historical take of time, needless to say, constitutes a contrast to the passing of a personal life-time, which previously dealt with. The poem ironically ends with a wish of a fairytale-like happy ending, which seems to be an illusion of the frozen moment, where nothing ever changes anymore. It is neither negative, nor positive, but an acceptance of this double face of time. It is again another specific space, the shade of a chestnut tree ("the first of the Paris chestnuts the granddaddy of them all / it came from Istanbul the hills of the Bosporus and settled in Paris") where this realization occurs.

The romantic interest, the mindset of a political refugee, coming terms with the past (and the historical material) -all of the themes are handled through the allegory of a journey and river: a journey that he will continue as an artist and a river flowing into the ocean of history of art. The succession of spaces and the constant alteration of locations refer to both the reconciliation of passing of time and also the hopeful joy of the change: a contradictory yet comforting point of view, which is reserved for artists.

\section{Conclusions}

Hikmet's masterpiece, the Straw-Blond, seems to be far away from the center of gravity of oeuvre, as he successfully flirts with a post-world war subjectivism, shaped by the legacy of Surrealism and a style that fits the post-war mood of anxiety and trauma. Straw-Blond's political material and historical narration are more of a decoration, and they only help to strengthen the conscious fragmentation of the text rather than emphasizing his realistic position as the poem does not reflect the solid foundations of linear narration. The wiggling mesh of love and loss, exploring and homesickness, past and present, tragedy and peace are instead presented through dynamism and pluralism.

The whole text is based on sudden movements from one place to another and the viscosity of the space around the passenger, which reminds the multiple vistas and space articulation of modernist architecture.

Hikmet rarely wrote about his taste of architecture. He was a supporter of using new materials and planning principles in architecture, as he put it in an article he wrote 
about architecture in the Soviet Union (HIKMET, [2015]). "By architecture a field of art," he wrote in a letter from prison a decade before, he means "the architecture of endless matter in constant motion" (HIKMET, [1968]). On the other hand, he underlined that the visual effects to arouse certain feelings- such as joy and respect instead of insipidity and tyranny- are more important. He also mentioned in 1935 that he is not a "fan of cubist" architecture as it usually turns to be a standardization wiping off the individual character of buildings [HIKMET, [1992]). Another group of newspaper articles from the same year praised the architectural heritage in Istanbul, the works of Sinan in particular, and the regional character of architecture in general as it reflects the taste and effort of the working class people (HIKMET, [1991]). If so, his position can be interpreted as modest modernism with a regional dose and expressionist character, namely some sort of late modern approach. It is fitting that he focused on the expressionist character of space in Straw-blond as a fluent yet subjective and complex entity given the non-linear narration and sophisticated take on the topics.

It is clear that no other poem relies so heavily on spatial composition. It is an extraordinary undertaking to use space as an intrinsic part of the text. The succession of spaces (thanks to the sudden jumps between them) is the main stylistic instrument of this multi-themed text revolving around the passing of the time. The spatial design, which is based on the succession of individual spaces, takes center stage as Hikmet puts an effort to mold a dynamic, fragmented yet a single space out of them. Thus, the cinematographic movement through the flow of spaces creates an architecture of narration to house the main emotion of the text -an anxious yet passionate interest towards to the thin and restless line between being and nothingness.

\section{REFERENCES}

[1] BACHELARD, G. ([1957] 1994). The Poetics of Space: The Classic Look at How We Experience Intimate Places. Beacon Press, Boston

[2] BAKHTIN, M. ([1938] 1981), The Dialogic Imagination: Four Essays, University of Texas Press, Austin

[3] BEKTAŞ, C., (2016), Nâzım Hikmet'in Mimarlığa Bakışı, Yap1 Endüstri Merkezi Yayınları, İstanbul

[4] BLASING, M. K. (2013), Nazim Hikmet: The Life \& Times of Turkey's World Poet, (Karen \& Michael Braziller Books), New York

[5] CEBECİ, O. (2013), Metafor ve Şiir Dilinin Yapısal Özellikleri, İthaki Yayınları, İstanbul

[6] DENNERLEIN, K. (2009). Narratologie des Raumes, de Gruyter, Berlin
[7] ELIOT, T.S. (2019). The Sacred Wood. New York: Alfred A. Knopf, 1921

[8] FUAT M. (2015), Nâzım Hikmet, Yapı Kredi Yayınları, İstanbul

[9] GÜRSEL, N. (2005), Dünya Şairi Nâzım Hikmet, Doğan Kitap, İstanbul

[10] HIKKMET, N. (2002) Poems of Nâzım Hikmet, trans. Randy Blasing and Mutlu Konuk, Karen and Michael Braziller Books, New York

[11] HIKKMET, N. (2007) Beyond the Walls, trans. Richard McKane, Ruth Christie, Talât Sait Halman, Carcanet Press Ltd.

[12] HİKMET, N. (2007), Bütün Şiirleri, Yapı Kredi Yayınları, İstanbul

[13] HİKMET, N. (2009) Human Landscapes from My Country: An Epic Novel in Verse, trans. Randy Blasing and Mutlu Konuk, Karen and Michael Braziller Books, New York

[14] HIKMET, N. [2015], Hayal Ediyorum: Mimariye Dair, TMMOB Mimarlar Odası İstanbul Şubesi, İstanbul

[15] HİKMET, N. [1992], Yazılar - I, Adam Yayınları, İstanbul, p. 88

[16] HİKMET, N. [1991] Yazılar - III, Adam Yayınları, İstanbul, p. 42

[17] HIKKMET, N. [1968] Kemal Tahir'e Mapushaneden Mektuplar, Bilgi Yayınevi, Ankara, p. 343-45

[18] KARACA, E. (2010), Nâzım Hikmet'in Aşkları, Destek Yayınlar1, İstanbul

[19] KARACA, E. (2011), Nâzım Hikmet'in Şiirinde Gizli Tarih, Destek Yayınları, İstanbul

[20] OBJECTIVE CORRELATIVE. (2019). In Glossary of Poetic Terms online. Retrieved from https://www.poetryfoundation.org/learn/glossary-terms/obj ective-correlative

[21] ÖZER, N. (2013) Nâzım Hikmet'in Memleketimden İnsan Manzaraları'nda İmajlar: Toplum, Tarih ve Sinema, unpublished Ph.D. Dissertation, University of Bilkent, Ankara

[22] PARKER, J. (2016). Conceptions of Place, Space and Narrative: Past, Present and Future, Amsterdam Journal for Cultural Narratology, 7-8, 74-101.

[23] RYAN, M.L. (2014): Space, the living handbook of narratology, eds. Hühn, Peter et al., Hamburg University, Hamburg [http://www.lhn.uni-hamburg.de/article/space] Access Date (15 Aug 2018)

[24] ZORAN, G. (1984), Towards a Theory of Space in Fiction, Poetics Today 5, 309-35.

\footnotetext{
i All cited poems are translated from Randy Blazing and Mutlu Konuk except mentioned otherwise. The poems veas only two main parts and although the subparts are not clearly recognizable, the poem is going to be analyzed in subparts separated according to cities and topics.
} 